\title{
The Existency of Traditional and Modern Dance in Medan City
}

\author{
Martozet \\ Performing Arts Department/Dance Education Department, Universitas Negeri Medan, Indonesia \\ sutanozet@gmail.com
}

\section{Abstract}

The purpose of this study was to determine the existence or existence of traditional dances and modern dances in Medan. The research problem focuses on the existence of these two dance forms, how is the journey of traditional dance forms from the preindependence era to the present and the glories of the emergence of new, modern-style dance forms from the 1960s, especially in the city of Meda. In order to approach this problem, the theory of existence is used WJS Poerwadaminta. Apart from that, it was also emphasized aboutunderstanding of traditional and modern dance by Indonesian dance expertsSoedarsono. While the data were collected through field observations, interviews, documentation, and literature study. Furthermore, the data obtained were analyzed through qualitative descriptive methods, narrating the data obtained in the field according to existing facts. From the research results it is known that the city of Medan as a large heterogeneous city, has traditional dances such as the Inai and Zapin Labuhan dances. Inai dance is performed at the evening ceremony, while Zapin Labuhan is performed at the apostolic circumcision ceremony.Zapin appeared in line with the existence of the Malays who lived in this area and were related to the existence of the Deli Sultanate. Zapin Labuhan developed during the reign of Tuanku Panglima Gandar Wahid in the 18th century AD, who was the King of Deli to $V$. Zapin.consists of several variants such as Zapin Anak Ayam, Zapin Pecah Tiga, Zapin Elang, Zapin Selendang, Zapin Lancang Kuning, Zapin Zat, Zapin Gergaji, and Zapin Zig Zag.

\section{Keywords}

reading material development; school literacy; movement

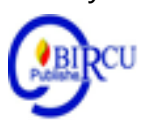

\section{Introduction}

Medan City is one of the cities in Indonesia that has experienced many changes and developments in its civilization, which tends to be dynamic and has a modern lifestyle. This development and progress can be seen from the social, economic, infrastructure elements, and no less advanced is the development of arts and culture, be it in the branches of fine arts, music, dance and other branches of art. Similar to other big cities in Indonesia, the development of dance is also influenced by the entry of other ethnicities outside of the local ethnicity, which creates new variants and diversities of the form and variety of dance performances in the city of Medan. So it is quite appropriate to say that Medan is a dynamic city, which also has an influence on dance forms and performances.

It is known that in human life, the presence of dance performances has various functions. This is influenced by the desire of the people who need it, both to fulfill aesthetic needs, ritual needs, to establish kinship values, even in needs that are influenced by religious values. Indonesian dance expert Soedarsono revealed that in human life, dance 
has various functions including as a means of religious ceremonies, as a means of traditional ceremonies, as a means of expressing joy or association, and finally it functions as a means of entertainment (Soedarsono, 1986: 22). We can still see the functions mentioned above in several regions in Indonesia, including in North Sumatra, especially the city of Medan.

The development of performing arts, especially dance, will not be far from the development and habits of the community as cultural owners. Given the heterogeneous and modern city of Medan, of course it brings a different color to the developing dances. Especially in new choreographic performances that are very different from traditional performances. Tradition is attached to binding rules, while modern is a work that contains contemporary elements. Sometimes in modern dance there are elements of tradition, which may be the root or kinesthetic stimulation for choreographers in presenting new works. Or it could be that a modern work is a work that is indeed separated from traditional values, meaning that it is purely a new innovation that is free from traditional colors.

If we talk about tradition, of course we will be brought to a form that was born from one generation to the next allied generations. This means that the tradition becomes part of their people and becomes an important necessity for their life. This tradition can be in the form of oral culture, norms in custom, and other life habits, including art and dance as one of them. The habits of our former primitive ancestors made dance a medium for unifying oneself from one group to another. Even as a communicative medium, the unification of the micro and macrocosmic universe is expressive. Soedarsono emphasized that what is called a traditional dance is a dance that has had a long history (Soedarsono: 1977: 29).

Based on the form, not all dances that have developed up to now can be said to be traditional dances. Even old dances are not necessarily considered traditional dances. Maybe it is a dance that was created for a long time, expressively and its form represents the existence of a certain people and is accepted by the society where it creates and develops. Based on the passage of time, it cannot be classified as a traditional art. Concrete examples are the Serampang XII dance by Sauti from the Serdang Bedagai area, North Sumatra and the Rantak dance by Gusmiati Suid from the West Sumatra region. The work of these two strong choreographers has represented the shape and character of their people and where it was created. Their work was well received, even people often think that the two dances are traditional dances from their respective regions. The precise point is that these two choreographed works are creations that are traditional for the society where these works are created grow and develop, even outside their territorial areas.

Tradition is something that is passed down from the heritage of the ancestors to the next generation in a relay descends performed by the indigenous communities that have become deeply entrenched the culture in life. Customs and traditions include the creation and work of human beings who have become convictions in regulating the social order of life. (Pane et al, 2020).

Tradition is something that often raises sacred elements, including in this case for performing arts. Art is an important part of ritual activities. Performing arts are part of the life of a society. He is present in a certain society because it is needed by the community concerned. It is not uncommon for performing arts to be in the circle of a society for certain ceremonial needs (AM Hermien Kusmayati, 1997: 1). Almost every ethnic group in Indonesia has ritual activities in the show. Although there are also traditional arts that do not contain sacred elements that are ritualistic, they are communal expressive forms. This is like the habit of dancing or in other terms manortor for the Toba Batak ethnic group in 
North Sumatra. Edi Sedyawati explained that every ethnic area in Indonesia has its own customs, and this custom is the main reason for the presence of dance performances (Edi Sedyawati, 1981: 113). Included in this are the customs and habits of the people in the city of Medan which are also related to the performing art form.

Tradition can be interpreted as inheritance or transmitted from the past to the present. In another sense, tradition is a behavior that is usually carried out by people in a certain social order in a hereditary wayl and has a system of ideas, concepts, thoughts, cultural values and norms.2 Such theories are widely written by W. Robertson Smith, J.Frazer, A. Van Gennep and R.Hertz who said that the origins of these beliefs arose because of an approach oriented towards rituals and religious ceremonies. (Faishal et al, 2019).

\section{Research Methods}

This research focuses on the existence of traditional dances and modern dances in the city of Medan. Two forms of performing arts, especially dance, where traditional dance has contributed to the diversity of modern dance forms that have developed in the city of Medan. The existence of these two different forms is studied using a qualitative method with a descriptive approach. Narrative clearly about the facts and data obtained in the field through interviews with several sources who know about the variety and form of dance performances in the city of Medan, and strengthened by literature studies covering literature related to the topic of study, as well as field surveys.

Existence is often referred to as an acknowledgment of a state in something that exists. This includes the state of traditional dance and modern dance in the city of Medan. WJS Poerwadaminta emphasized that the notion of existence is presence, which comes from the word "being" (WJS Poerwadarminta, 2001: 5). With a special meaning that existence is associated with something that already exists, be it something old, even something new and becomes something meaningful for the supporting community, in this case the existence of traditional and modern dance in the city of Medan.

\section{Discussion}

\subsection{The Existence of Traditional Dances in the City of Medan}

Medan is the third largest city in Indonesia after Jakarta and Surabaya. Similar to other cities in Indonesia, the people of Medan have a dynamic and modern lifestyle. The arrival of other tribes, especially those in Indonesia and other foreign tribes, has never ended in the history and development of this city. Known for its heterogeneous society, this city is populated by people with different cultural and religious backgrounds. Apart from the Malay and Karo tribes as the initial inhabitants, Medan is dominated by ethnic Javanese, Batak, Chinese, Minangkabau, Mandailing and Indian (https:/id.wikipedia.org/wiki/Kota_Medan). Apart from the dominating tribes mentioned above, of course Medan is also inhabited by the original tribes of North Sumatra which consist of eight main tribes including the Malay, Karo, Toba, Mandailing, Sibolga, Simalungun, Pakpak, and Nias tribes with a large population. different.

Medan city area consists of twenty one districts. The city of Belawan is the northern tip of the city of Medan which also functions as a gateway to economic activity and the entry point for tourists by sea. Meanwhile, Medan Tuntung is the southern tip of the city of Medan, which borders the Regency of Deli Serdang. Medan is a big city, but the existence 
of traditional arts is maintained even though it is chasing the progress of civilization as an identity.

As a center for the development of arts in the North Sumatra region, the city of Medan has a variety of performance forms, especially dance. However, in accordance with its existence as a metropolitan city, this city does not have too many traditional dance forms. If traced, there are two forms of traditional dance that have developed in the city of Medan, the first is a traditional dance group that geographically grows and develops in this city area. While the second group is a traditional dance that comes from outside the city of Medan. This second group is usually studied by dancers from Medan in dance studios built by professional artists.

Based on existing literature, that the first tribes to occupy the city of Medan were the Malays and the Karo tribes. Evidence and the existence of the Malay tribe who settled themselves in the city of Medan with the existence of the Maimun palace, as the Deli Sultanate palace which was founded on August 26, 1888, which until now is 132 years old. However, the Deli Malay Sultanate, previously known as the Aru Kingdom, was founded in 1632 by Tuanku Panglima Gocah Pahlawan in an area called Tanah Deli (now Medan city and Deli Serdang Regency) (https://id.m.wikipedia.org). Besides that, it was also strengthened by the presence of one of the oldest mosques in the city of Medan, which coincided with the construction of the Deli Sultanate palace.

Meanwhile, the formation of the Karo tribe in Medan is marked by the appearance of a character named Guru Patimpus Sembiring Pelawi, who is the son of Tuan Si Raja Hita, the leader of the Karo tribe. Guru Patimpus Sembiring Palawi in 1590 is seen as opening a village called Medan Puteri (https://id.wikipedia.org/wiki/History_Kota_Medan). There is information that explains that Guru Patimpus is the founding figure of the city of Medan. However, there is not much data or literature that explains the historical existence of this city. To remember the character of Guru Patimpus who came from the Karo tribe, the Medan city government made the name of one of the roads in the city of Medan under the name Guru Patimpus.

With the rapid development of the area, many other tribes also migrated to this city. Especially other tribes in North Sumatra such as the Batak, Karo, Mandailing, Nias, Pakpak, and even other tribes that developed in Indonesia such as Javanese and Minangkabau tribes as well as foreign migrants such as Chinese and Indian. From this history, it can be seen that traces of traditional arts, in this case dance, are growing and developing, influenced by the existence of ethnic groups in the city of Medan. Based on an interview with one of the artists in the city of Medan Baharuddin, the Malay tribe is a tribe that shows a strong existence in the city of Medan, especially in Medan Labuhan with the appearance of traditional dances (interview at Taman Budaya Sumatra Utara, 27 August 2020).

Traditional dance that grows and develops in the city of Medan is a dance that is influenced by Islamic culture inherent in ethnic Malay, because Malay is synonymous with Islam. Traditional dances that still exist in the city of Medan are the zapin dance that has Islamic values and the Inai traditional dance that grows and develops in the Medan Labuhan area. Whether this type of dance is related to the emergence of ethnic Malays in the city of Medan, of course, can be traced based on the history of the emergence of ethnic groups in this city. The common thread regarding the relationship between the arrival of the Malays in the city of Medan and the emergence of the zapin and Inai dances, especially in Medan Labuhan, is very strong and logical.

Inai dance is a traditional dance whose performance is performed at the wedding ceremony of the Malay tribe in Pekan Labuhan Village, Medan Labuhan. This dance is 
performed on an initiated night which is performed the day before the marriage contract and is performed at night after the evening prayer (Debbi Yolanda Putri, 2017: 4) Until now, the Inai dance has survived in the life conditions of the people of Medan, which are dynamic and have a modern lifestyle. Historically, this traditional dance has been studied from generation to generation in line with the appearance of the Malay tribe since ancient times in the city of Medan, in accordance with the theory presented by Soedarsono that traditional dance is a dance that has had a long history. A long journey and the growth and development of traditional Inai dance in the city of Medan,

Another traditional dance that has developed in the city of Medan is the zapin genre dance whose ownership comes from the Malay tribe, which is also in the Medan Labuhan area, especially the Pekan Labuhan area, Kampong Besar, and the Rengas Island area. In general, people know and call him Zapin Labuhan, and part of the community knows him with the term Lenggok Gambus. But musically, this type of dance is a zapin genre group, although it is also known as Lenggok Gambus which consists of eight dance forms. The eight dances include Zapin Selendang, Zapin Zig-Zag, Zapin Zet, Zapin Gegaji, Zapin Elang, Zapin Lancang Kuning, Zapin Anak Ayam, Zapin Pecah Tiga.

Historically this dance has appeared in the Labuhan area for a long time, in line with the existence of the Malays who live in this area and are related to the existence of the Deli Sultanate. Zapin Labuhan developed during the reign of Tuanku Panglima Gandar Wahid in the 18th century AD, who was the 5th King of Deli. During the development of the tobacco trade during the IXth era of King Deli, in 1886 the center of the Deli kingdom moved to Medan. (Rizky Firdalia, 2015: 3). Now young people are participating in learning this dance, as the next generation so that they are not swallowed up by the progress of the times and increasingly sophisticated and sophisticated technology. Artists in Medan are also maintaining the continuity of this traditional art by learning and performing it. Other than that, Medan city government through the Culture Office takes part in preserving the development of this traditional art by holding a Zapin Labuhan workshop. This activity was attended by art teachers and dancers from Medan which was held on April 14 and 152017 at the Madani hotel and was trained by Medan city artists such as Retno Ayumi, Sahrial Felani, Abdul Rahman, Syahbilal, and Rudi.

\subsection{The Existence of Modern Dance in Medan City}

Modern dance is a genre that is rapidly developing in the city of Medan. This development can be seen from Bentuk or a form of dance, as well as a festival event that is held, as well as an interaction between dance artists in the city of Medan. The diversity of shapes and forms is related to the choreographer's taste and ego as the creator. This is where we can see creativity and contemporary forms, in this case the modern values contained in the choreography created. In fact, a choreography that contains cross culture values appears, so that it seems unique and gives birth to new shapes and styles.

Referring to contemporary Indonesian dictionaries that the word modern means; new ways, new fashions, new creations, and cutting-edge (M. Dahlan Yacub Al Barry, 2001: 449). With regard to modern dance that has developed in Medan, the term above is indeed appropriate in that the dances created by the choreographers of the city of Medan are creating new works in new ways. Especially regarding the form of work and movement techniques that are common in choreography in modern contexts. However, even with new ways, new fashions and styles, where the tendency of choreographers to adopt traditional forms as their own sember seems very dominant.

Confirming the opinion about modern dance, especially in the city of Medan, of course the form is different from other regions in Indonesia. However, the tendency of 
Indonesian choreographers is to make traditional forms as their roots in their work. Modern Indonesian choreographers such as Huriah Adam, Retno Maruti, Bagong Kusudiarjo, Sardono W. Kusumo, Gusmiati Suid, Boy G Sakti, Eri Mefri, Miroto, and Eko Supriyanto are modern Indonesian choreographers who were very productive in their respective eras. All of them are very firmly based on their roots and traditions where they come from, but their choreography has been touched by modern values. The modern values contained in their works can be seen from the form of choreography that carries broad themes that are common in modern dance works.

Tran Van Khe is a professor of ethnomusicology from Vietnam. He said that modernization does not mean oriented to the west. This means that dance forms that are said to be modern are not always identical with works of imitation from the west. All forms of movement, whether they are extracted from the current situation, or from the aspects of traditional culture, can be used as sources of modern dance work. It is clear that the modern dance form is freedom in expressing the technique of movement on the stage (Soedarsono, 1986: 96). The author clearly remembers Soedarsono's explanation that being modern does not mean being westernized. Taking the roots of tradition and making it a new material can be said to be modern. This statement he conveyed at a dance seminar at the Indonesian Arts College,

In modern works there is basically no need to lose cultural roots, which is the case with choreographers from European and American countries. Many famous choreographers from these two countries are rich in modern styles, even absurd and want to get away from the boring ballet techniques and forms as their tradition. But as far and as modern as they are in their work, still ballet technique as a tradition that forms them cannot be abandoned one hundred percent. They consider ballet as a limited expression, and are considered rigid that only prioritizes technique. But they have all studied ballet professionally. Then they express themselves more broadly and freely, and can express their emotions through creativity in forming dance and breaking away from binding traditions. As the example of the famous choreographer from the United States Martha Graham, she is very well known and popular with her unique motion idiom and with a choreographed form that is always new, and very, very different from the ballet dance form that is taken for granted. In addition, there were Pina Bausch, Sasha Waltz, Merci Cunningham Isadora Duncan, Ruth St, Denis, Doris Humphrey and other modern choreographers.

Edi Sedyawati explained about modern dance, that to be modern you don't need to lose your national identity. Modern predicates are also about attitudes and views and not just form, meaning that modern works can also be created with new feelings and emotions. Furthermore, according to Myron Weiner's opinion, in his book 'Modernization: The Dynamics of Growth" 1996 (quoted in Edi Sedyawati's writing) that modernization is characterized by the following characteristics: the excitement of creativity and skill development, the perceived importance of work and the ability to stand alone ( Edi Sedyawati, 1981: 123). Referring to Myron Weiner and Edi Sedyawati's opinion is that modernization in a choreography is a view that is free of ideas and the emergence of new creativity that can be based on regional values.

According to F Nangkir Saragih, the development of modern works in the city of Medan has long since occurred after the era of Indonesian independence. However, in the early 1960s, there was an era in which new works by choreographers such as OK Adram, Sauti, Taralamsyah Saragih, F, Nangkir Saragih, and Tengku Sita Saritsyah emerged. The development of modern dance in the city of Medan has shown brilliant results, where $\mathrm{F}$ Nangkir Saragih as a choreographer was awarded an award in a national dance 
competition. The choreography, entitled Tortor Turahan, has the theme of mutual cutting in wood cutting. This event was held by the central government of Jakarta in 1978 (F Nangkir Saragih, 1975: 94). From some of the choreographers mentioned above, the authors have difficulty in obtaining data about the works of them as carriers of renewal and modernization in the city of Medan. Only the work of the choreographer Tengku Sita Saritsyah can the writer see firsthand and find the data of his work to represent the opening generation of modern works in Medan.

Choreographer Tengku Sita Saritsyah is a senior choreographer, as well as one of the pioneers of the path for other young choreographers in creating new innovations in Medan. Tengku Sita Saritsyah is the son of Tengku Rajih Anwar and Ncik Nelly. His parents are descendants of the Deli Sultanate, so that his works are strongly influenced by the culture in which he was born, namely the Malay tribe. Tengku Sita Saritsyah existed in creating dance in the era of the 1960 s to the end of 1990 . The ability to organize dances was selftaught without tasting formal knowledge in the field of dance creation. Some of the modern-style choreographies that he created are very thick with Malay elements, which are displayed at art festival events in the city of Medan. In the middle of 1968, with the art team of the Bukit Barisan Ensambel in Medan, he was trusted as a choreographer to present his work in Penang and Kuala Lumpur, Malaysia. His choreography at that time was entitled Tun Tedja, Mak Inang Selendang, and Dodoi Si Dodoi. By Tengku Sita Saritsyah, these three choreographies are referred to as the triumvirate dance (Martozet, 2003: 66).

In 1980, Tengku Sita Saritsyah created a dance drama entitled Rama and Shinta, which took the epic Ramayana as a theme as well as an idealistic stimulus. He performed this dance drama in a modern Malay style and by combining elements of Malay silat as a basis for developing movement as well as a kinesthetic stimulation that gave birth to a unique form of work at that time. There is also Tengku Sita Saritsyah's popular work, namely the choreography of Ulah Rentak Angguk Terbina, created in 1988. Then a year after that, he was trusted by the Garuda Indonesia company to present some of his works in London, England to commemorate the company's 40th anniversary. Many of his works are displayed at important festivals at the regional level, nationwide and in foreign countries such as England, France, Germany, Spain, and South Africa. Almost all of the choreography created by Tengku Sita Saritsyah is rooted in Malay elements. In the era of the $60 \mathrm{~s}$ to the end of the $90 \mathrm{~s}$, his choreography gave a new color to the development of modern dance in the city of Medan. Modern values can be seen from the form of motion, presentation patterns, clothing, and other dance elements, although the floor patterns in the choreography mostly use symmetrical patterns.

Another senior choreographer for Medan is Yose Rizal Firdaus, who existed in arranging dances in the era of the 1970s. Unlike his seniors, as the second generation Yose Rizal Firdaus has begun to be a bit brave enough to form choreography with a wider movement pattern. He mastered many dance styles that developed in Indonesia apart from the eight dance styles that developed in North Sumatra. In fact, he has mastered the types of Cha-Cha, Bugi-Bugi, and Rumba dances, as well as martial arts and martial arts until he reaches the Dan-II level. Mastery of martial arts and mastery of several dance styles and techniques have become the main assets for Yose Rizal in creating new choreographies with modern styles. In his opinion Sauti, Anjang Nurdin Paitan, OK Adram, and OK Terai, are the people and teachers who are influential in shaping him into a dancer (Martozet 2003: 71). It is known that many people are capable of dancing, but not many are able to create dances well. Only Yose Rizal Firdus is much different from the dancers of his age, 
where he has the instinct to create dance well even though he has an educational background as a law degree.

In the early 1970s he was appointed by the Medan City Department of Education and Culture as a dance coach at the school in the arts. In line with that, he has started to create dances that are displayed at cultural events in the city of Medan. With time and his career as an artist, he became increasingly critical of the development of dance in North Sumatra, especially the city of Medan. Furthermore, based on his experience in following dance development in Indonesia, he wrote a book about dance for students in schools which was eventually used in the 1973 education curriculum in North Sumatra. Then in 1978, Beliu had the opportunity to perform at the Sumatran Art Week. At this prestigious event in the Sumatra region, he performed a choreography with the title Mengemping, which has the theme of the daily activities of the Malay people who make food in the form of chips. From this activity, he felt challenged to create other new works.

His works include Sulalah, Zikri, Malang Tak Sudah, Keris, Lonjak Lajang and Dara, Zapin Gembira, Zapin Astakona, Persembahan, and Menghanyut Lancang choreography. He has also made choreography in a dramatic format with the title Panglima Nayan, which was performed at art festivals in Medan and outside Medan, and worked on repeatedly in different formats. In 1982 he made a choreography with the title Hadrah, which was performed at Taman Ismail Marzuki, Jakarta and continued to appear at the same event in 1984 with the title choreography Imbas. Apart from being performed at the regional and national levels, his choreography has also appeared in several countries such as Switzerland, Germany, the Netherlands, the United States, Japan, Morocco, and several Asean countries.

Yose Rizal Firdaus' choreography which is still being studied is Zapin Towards Maghrib. This dance represents a modern form of choreography in the 80 s era, where choreographically it looks different from traditional patterns. The designs and forms of motion in this choreography appear to be more open, with traditional forms that tend to be introverted or with a slightly closed style according to Malay ethics. The broader motion design that appears in the choreography of Zapin Menjelang Magrib has given new colors to modern works in Medan. This choreography appears soft and flowing, but dynamic impressions can be felt through the harmoniously arranged movement patterns. Because he has a lot of skills and knowledge in the field of dance, he was an extraordinary lecturer in the Dance Education Study Program. majoring in Sendratasik, Medan State University. He also served for two terms as chairman of the North Sumatra Arts Council from 1991 to 1999.

After the appearance of the two senior choreographers above, the stretch and pulse of modern dance developments in the city of Medan are increasingly shining and never breaking. In the era of the 1990s, other choreographers with different characters appeared, such as Anton Sitepu, Syahrial Felani, Muhamad Nursyam, Dwi Sulistiono, Iskandar Muda, Agung Suharyanto, and other choreographers. These young choreographers gave new colors to the development of dance in Medan.

From the writer's observation who saw their performances directly, either singly or at festival events in Medan, it is known that the form of their choreography is very different from their predecessors. Where modernization and individual choreographer egoism in this era can really be felt. Their movement patterns are very much different from traditional styles, even though they very clearly make traditional forms a source of movement development. Apart from the form and pattern of the choreography, the modern value that is very thick in these choreographers is the floor pattern which is formed with an asymmetrical pattern which seems more vibrant and dynamic as one of the characteristics of 
modern-style works. Very much different from the floor pattern in traditional dance which is symmetrical.

In their choreography, the dancers' bodies appear to be getting wilder on stage, and sometimes they also include technological elements in the choreography they make. As in the choreography of Api Yang Tak Never Padam, Dwi Sulistiono's work, which was created in 2001. At the beginning of his choreography he presented a short documentary film related to the dance theme he chose. Then he made a silhouette technique in the middle of the choreography which created a very strong visual and artistic effect. Another case with Muhamad Nusryam's choreography with the title Gentam Sirat Rebana, he also has a modern style by forming different motion patterns, but creating a unified and harmonious effect. This choreography uses the tambourine property, which is processed by a choreographer with such a design, which is not only held in hand, but also played by throwing into the air and being caught again by a moving dancer. So that in this section it creates an acrobatic impression and seems to give birth to several different focus points.

From the anxiety of post modern choreographers in Medan, they form several festival events regularly. Apart from being a place for self-existence and friendship between dance artists in the city of Medan, dance festival events such as the Medan Annual Choreographer Showchase were formed from 1991 to 1993 . Then the event of the Medan City Dance Community festival which was formed in 2019 until now is centered in North Sumatra Cultural Park. This new event every month features new works of talented young choreographers from the city of Medan. From this festival, it can be seen that the pulse of modern dance development in the city of Medan is getting stretched, in accordance with the modern and dynamic life of its people.

\section{Conclusion}

Dance performance, both traditional and modern, is the responsibility of the artist and his community as cultural owner. Traditional dances are noble works that are owned collectively by certain communities and it is often unknown who the creators are. It has been studied from generation to generation from one generation to another, as is the case with the Inai and zapin dances which still exist in the city of Medan, especially Medan Labuhan. Zapin in Medan Labuhan must be preserved as a cultural heritage for the next generation, so that they do not lose the cultural roots where it grows and develops.

Meanwhile, modern dance groups in the city of Medan are developing very rapidly in accordance with the development of this city, which began with the appearance of Tengku Sita Saritsyah. After that, a generation like Yose Rizal Firdaus emergedat influencing the development of new dance designs that breathe modern in the city of Medan. The development of modern dance in the city of Medan is also influenced by the existence of dance festivals in this city. The progress of modern dance in Medan is getting wild and conducive with the emergence of productive choreographers such as Anton Sitepu, Nurwani, Syahrial Felani, Muhamad Nursyam, Dwi Sulistiono, Iskandar Muda, Agung Suharyanto. Their choreography gives a new color to the development of modern dance in this city, which has also influenced the birth of new generations as dance creators, in this case choreographers. 


\section{References}

A.M. Hermien Kusmayati (1997), Peddug : Seni Pertunjukan Dalam Upacara Rokat Padabha di Madura, Jurnal Seni Pertunjukan Indonesia, Masyarakat Seni Pertunjukan Indonesia

Debbi Yolanda Putri (2017), Makna Tari Inai Pada Masyarakat Melayu Desa Labuhan Kota Meda, skipsi S-1 Jurusan Sendratasik, Program Studi Pendidikan Tari, Fakultas Bahasa dan Seni, Universitas Negeri Medan

Edi Sedyawati (1981), Pertumbuhan Seni Pertunjukan, Sinar Harapan Jakarta

F. Nangkir Saragih (1975), Bidang Studi Kesenian Sub Bidang Studi Seni Tari, Departemen Pendidikan dan Kebudayaan

Faishal, M., et al. (2019). Trust on Tradition/Customs of Batu Bara Community in the $19^{\text {th }}$ Century. Budapest International Research and Critics Institute-Journal (BIRCIJournal). P. 567-574

M. Dahlan Yacub Al Barry (2001), Kamus Besar Bahasa Indonesia Kontemporer, Jakarta

Martozet (2003), Suatu Kajian Teknik Penataan Tari Lima Orang Koreografer Kota Medan, Sumatera Utara, Tesis Master, Universiti Sains Malaysia

Pane et al. (2020). The Performance of Mangupa Tradition in Angkola Custom, Medan, Indonesia. Budapest International Research and Critics Institute-Journal (BIRCIJournal). P. 1747-1757

Rizky Firdalia (2015), Bentuk Pertunjukan Tari Zapin "Z" Pada Masyarakat Melayu Labuhan Deli, skipsi S-1 Jurusan Sendratasik, Program Studi Pendidikan Tari, Fakultas Bahasa dan Seni, Universitas Negeri Medan

Soedarsono. (1986), Pengantar Pengetahuan Tari dan Komposisi Tari, Direktorat Kesenian, Proyek Pengembangan Kesenian Jakarta, Departeman Pendidikan dan Kebudayaan

Soedarsono. (1997), Tarian-Tarian Indonesia I, Proyek Pengembangan Media Kebudayaan Poerwadaminta, W.J.S (2001), Kamus Besar Bahasa Indonesia, cetakan pertama, edisi III, Jakarta : Balai Pustaka

Internet Sources:

https//id.wikipedia.org/wiki/Kota_Medan

https $/ /$ id.wikipedia.org/wiki/Sejarah_Kota_Medan 